Original Article

\title{
ANTI-MRSA OF THE ETHYL ACETATE CRUDE EXTRACT FROM LASIODIPLODIA PSEUDOTHEOBROMAE IBRL OS-64, AN ENDOPHYTIC FUNGUS ISOLATED FROM LEAF OF OCIMUM SANCTUM LINN
}

\author{
TAUFIQ M. M. J. . $^{*}$ DARAH I. ${ }^{2}$ \\ 1,2Industrial Biotechnology Research Laboratory, School of Biological Sciences, Universiti Sains Malaysia, 11800 Minden, Penang, Malaysia \\ Email: fiqz04@yahoo.com.sg \\ Received: 18 Feb 2017 Revised and Accepted: 27 Jun 2018
}

\begin{abstract}
Objective: To investigate the effects of ethyl acetate crude extract of an endophytic fungus, L. pseudotheobromae IBRL OS-64 which was isolated from leaf of Ocimum sanctum against the growth of methicillin-resistant Staphylococcus aureus (MRSA)., a common pathogenic bacteria to human.
\end{abstract}

Methods: Minimal inhibitory concentration (MIC) and minimal bactericidal concentration (MBC) were determined. Time-kill assay was used to examine the effect of the extract on the MRSA growth profile. The effects of the extract on the ultrastructure of MRSA cells were analyzed by scanning electron microscopic (SEM) study.

Results: The results obtained from this study showed the fungal ethyl acetate crude extract exhibited a strong bactericidal effect on MRSA where the ratio of MBC/MIC was 2 and less than 4 . The MIC and MBC values were 125.0 and $250.0 \mu \mathrm{g} / \mathrm{ml}$, respectively. The time-kill study revealed that the bacteriocidal activity of the extract was both concentration and time-dependent. After $12 \mathrm{~h}$ treatment, the interaction of extract with MRSA cells resulted in the formation of dents, cavity or small dimples on the cell surface, indicating disintegration of the cell wall and cell membrane that resulting in leakage of their cytoplasmic contents, and ultimately cell death.

Conclusion: The ethyl acetate crude extract of L. pseudotheobromae IBRL OS-64 showed a significant anti-MRSA activity and principally affected the cell wall and the cell membrane of the growing MRSA cells. This is the first report on L. pseudotheobromae, an endophytic fungus isolated from medicinal herb, Ocimum sanctum Linn.

Keywords: Endophytic fungus, L. pseudotheobromae, Anti-MRSA activity, Cell structure degeneration, Minimal Inhibition Concentration (MIC), Minimal Bactericidal Concentration (MBC), Time-kill study

(C) 2018 The Authors. Published by Innovare Academic Sciences Pvt Ltd. This is an open access article under the CC BY license (http://creativecommons.org/licenses/by/4.0/) DOI: http://dx.doi.org/10.22159/ijpps.2018v10i8.26527

\section{INTRODUCTION}

Starting with the early reports of antibiotic resistance towards penicillin and sulphonamides just after the World War II, it then involved many other cases of antibiotic resistance occurred including the establishment of MRSA, a pathogenic strain of Staphylococcus aureus that resistant to methicillin [1], It is one of the human pathogens that involved in nosocomial acquired infection and caused serious infectious diseases with high rate in morbidity and mortality [2]. Ocimum sanctum Linn is a medicinal herb that is known locally as basil or 'selasih hitam' in Malaysia can be found commonly planted in home gardens due to its traditional uses and medicinal values [3]. Traditionally, the plant is used to relief common cold, bronchitis, cough and digestive problems [4]. Besides that, researchers have proven that various part of this plant exhibited antibacterial [5], antifungal [6], and antioxidant [7] and insecticides properties [8]. Microorganisms such as endophytes have been recognised as a potential source of novel bioactive compounds with promising antimicrobial activity [9]. Endophytic fungi can be defined as highly diverse microorganisms that live within plant tissues of their host but remain asymptomatic [10]. High diversity of endophytic fungi associated with medicinal herbs is observed and their distributions, as well as composition, are affected by tissues and hosts [11]. Lasiodiplodia pseudotheobromae has long been recognised as a common pathogenic fungus found on a variety of host plants in the tropics and subtropics. It causes numerous diseases, in particular, causing rotting of fruits and root crops during storage. It was reported as a plant pathogenic fungus which caused trunk cankers in Acacia mangium in Venezuela [12], postharvest fruit rot of lemon in Turkey [13] and persimmon rot in Brazil [14], besides causing dieback disease of mango in Egypt $[15,16]$. In searching for symbionts derived from bioactive natural products, Wei [17] found the isolate L. pseudotheobromae F2 which was isolated from a flower of Illigera rhodantha exhibited significant antibacterial activity. Furthermore, Cimmino [18] also reported the antibacterial activity exhibited by the L. pseudotheobromae isolated from the grapevine. The aim to this study was to investigate the effects of ethyl acetate crude extract of an endophytic fungus, $L$. pseudotheobromae IBRL 0S-64 which was isolated from the leaf of $O$. sanctum against the growth of MRSA.

\section{MATERIALS AND METHODS}

\section{Endophytic fungus, culture and maintenance}

The endophytic fungus previously isolated from the leaf of Ocimum sanctum Linn. was provided by the culture collection of the Industrial Biotechnology Research Laboratory (IBRL), Universiti Sains Malaysia, Penang, Malaysia. The fungal isolate was cultured and maintained on potato dextrose agar (PDA) (Merck, Germany) supplemented with powdered host plant $(2.0 \mathrm{~g} / \mathrm{l})$ and incubated at $30{ }^{\circ} \mathrm{C}$ aerobically for $7 \mathrm{~d}$ before storing it at $4{ }^{\circ} \mathrm{C}$ prior to use. The isolate was subcultured on sterile fresh medium once a month to ensure its purity and viability.

\section{Culture medium}

Yeast extract sucrose broth (YES) (Merck, Germany) which contained (g/l): yeast extract, 20; sucrose, 40.0 and magnesium sulphate, 0.5 was added into $1000 \mathrm{ml}$ distilled water supplemented with $O$. sanctum leaf water extract [19]. The host plant extract was prepared by boiling $1.0 \mathrm{~g}$ of the powdered leaf in $500 \mathrm{ml}$ distilled water for $30 \mathrm{~min}$. The mixture was then filtered through filter paper (Whatman, No. 1) and the filtrate was mixed with freshly prepared culture medium, followed by autoclaving at $121{ }^{\circ} \mathrm{C}$ for $15 \mathrm{~min}$. The medium was used to cultivate the endophytic isolate in a shake-flask system. The $\mathrm{pH}$ of the culture medium was adjusted to $5.8 \pm 0.2$. 


\section{Cultivation and extraction}

The inoculum was prepared by introducing two mycelial agar plugs approximately $1.0 \mathrm{~cm}$ in diameter and $4.0 \mathrm{~mm}$ thickness, which were excised from the periphery of $7 \mathrm{~d}$ old endophytic fungal cultures into $250 \mathrm{ml}$ Erlenmeyer flasks containing $100 \mathrm{ml}$ of YES broth medium. The cultures were cultivated at $30^{\circ} \mathrm{C}$ with an agitation speed of $120 \mathrm{rpm}$ for $20 \mathrm{~d}$ in the dark. After the incubation period, the fermented broth and fungal biomass were separated out using filter papers (Whatman, No. 1). The filtered broth was extracted thrice with an equal volume of ethyl acetate $(1: 1, v / v)$. The upper organic phase was collected and subsequently was concentrated to dryness under reduced pressure in a rotary evaporator to obtain the ethyl acetate crude extract paste. Due to the antibacterial activity exhibited by $O$. sanctum, a control was included by extracting the sterile medium following exactly the same procedure as that for the endophytic cultures.

\section{Test microorganisms}

The Methicillin-resistant Staphylococcus aureus ATCC 33591 culture was provided by the Industrial Biotechnology Research Laboratory, Universiti Sains Malaysia, Penang, Malaysia The bacterial culture was grown on nutrient agar (NA) (Merck, Germany) and incubated at $37^{\circ} \mathrm{C}$. The inoculum suspension was prepared by picking up five single isolated colonies from $24 \mathrm{~h}$ old culture and transferred them into $5.0 \mathrm{ml}$ of $0.85 \%$ sterile physiological saline $(\mathrm{w} / \mathrm{v})$. The turbidity of the bacterial suspension was adjusted to match 0.5 McFarland standards (approximately $1 \times 10^{8} \mathrm{CFU} / \mathrm{ml}$ ).

\section{MIC and MBC determinations}

The minimal inhibitory concentration (MIC) of the fungal ethyl acetate crude extract was determined by broth microdilution assay as described by Jorgensen and Ferraro [20] with some modifications. The broth microdilution was conducted in a sterile, 96-well, U-shaped microtiter plate (TPP, Switzerland). A single-fold dilution of the fungal extract was prepared in sterile Muller Hinton Broth (MHB) (Merck, Germany) medium and $100 \mu \mathrm{l}$ of the extract was dispensed into each wells of a microtiter plate. On the other hand, $100 \mu \mathrm{l}$ of bacterial inoculum at approximately $1 \times 107 \mathrm{CFU} / \mathrm{ml}$ was added into each of the wells for a final volume of $200 \mu \mathrm{l}$ and the final concentration of bacterial in each wells was $1 \times 107 \mathrm{CFU} / \mathrm{ml}$. Chloramphenicol (SigmaAldrich, USA) was used as a reference drug and a control with $5 \%$ methanol and bacterial inoculum was included. After a $24 \mathrm{~h}$ of incubation period at $37^{\circ} \mathrm{C}, 40 \mu \mathrm{l} \mathrm{of} 0.2 \mathrm{mg} / \mathrm{ml} \mathrm{p}$-iodonitrotetrazolium violet (INT) (Sigma-Aldrich, USA) dissolved in 99.5\% ethanol solution was loaded to each wells as a growth indicator. The MIC value was determined and recorded as the lowest concentration of the ethyl acetate crude extract that capable to inhibit the visible growth of test bacteria after $24 \mathrm{~h}$ of incubation period [21].

Minimal bactericidal concentration (MBC) of the fungal ethyl acetate crude extract was subsequently determined upon reading of minimal inhibitory concentration (MIC) value. The viable cell was enumerated on Mueller Hinton agar (MHA) (Merck; Germany) by a standard viable plate count after $24 \mathrm{~h}$ of incubation period at $37^{\circ} \mathrm{C}$ for overnight. The MBC was observed and recorded as the lowest concentration of fungal ethyl acetate crude extract that resulted in a reduction of $99.9 \%$ bacterial growth relative to the growth control.

\section{Time-kill study}

In the time-kill study, the ethyl acetate crude extract was tested at concentrations of $1 / 2 \mathrm{MIC}, \mathrm{MIC}$, and 2MIC. Prior to that, the minimal inhibitory concentration (MIC) value of MRSA which was 125.0 $\mu \mathrm{g} / \mathrm{ml}$ was used. A volume of $0.1 \mathrm{ml}$ of bacterial suspension (approximately $1 \times 10^{7} \mathrm{CFU} / \mathrm{ml}$ ) was introduced into $50 \mathrm{ml}$ Erlenmeyer flask containing $19.9 \mathrm{ml}$ of MHB with different concentrations of extract yielded the initial bacterial suspension of approximately $5 \times 10^{7} \mathrm{CFU} / \mathrm{ml}$. For comparison, the inoculum consisted of bacterial culture and 1\% Dimethyl sulfoxide (DMSO; $\mathrm{v} / \mathrm{v}$ ) in MHB was set as a control. The cultures were subsequently incubated in a rotary orbital shaker (Lab-Companion, Korea) at 37 ${ }^{\circ} \mathrm{C}$ with agitation rate of $150 \mathrm{rpm}$ for $48 \mathrm{~h}$. A volume of $0.1 \mathrm{ml}$ of the aliquot was withdrawn for viable cell count at every 4 hourly during the time intervals of 0 to $48 \mathrm{~h}$. The samples were diluted and spread onto fresh nutrient agar plates followed by incubating at $37^{\circ} \mathrm{C}$ for 24 $\mathrm{h}$ and the viable bacterial colonies were then counted. To determine the colony unit per millilitre $(\mathrm{CFU} / \mathrm{ml})$, only the plates with the number of colonies ranging from 30-300 were counted. A time-kill curve (log $\mathrm{CFU} / \mathrm{ml}$ vs. time) was plotted for each extract concentrations and control. At the meantime, the growth reduction in which the time to achieve $50 \%, 90 \%$, and $99.9 \%$ of bacterial cells reduction was calculated according to equation 1 . The experiment was carried out in triplicates on separate occasions.

$$
\text { Growth reduction }=\frac{V_{i}-V_{z}}{V_{z}} \mathrm{X} 100
$$

Whereby $V_{i}$ is the initial viable cell count and $V_{z}$ is the viable cell count at $\mathrm{z}$ time.

\section{Scanning electron microscopy (SEM)}

For sample preparation, $50 \mu \mathrm{l}$ of bacterial inoculum (approximately $1 \times 10^{8} \mathrm{CFU} / \mathrm{ml}$ ) was transferred into a $25 \mathrm{ml}$ Erlenmeyer flask containing $945 \mu \mathrm{l}$ of MHB and incubated in an orbital shaker at 37 ${ }^{\circ} \mathrm{C}, 150 \mathrm{rpm}$ for $18-20 \mathrm{~h}$. A volume of $0.5 \mathrm{ml}$ of ethyl acetate crude extract $(2.5 \mathrm{mg} / \mathrm{ml})$ was added into the bacterial culture after incubation period to yield a volume of $10 \mathrm{ml}$ mixture with extract concentration of $0.25 \mathrm{mg} / \mathrm{ml}$. At the meantime, $0.5 \mathrm{ml}$ of $20 \%$ DMSO $(\mathrm{v} / \mathrm{v})$ was added into the bacterial culture as a replacement to the extract and served as control. The mixture was then incubated at 37 ${ }^{\circ} \mathrm{C}, 150 \mathrm{rpm}$ for $36 \mathrm{~h}$. The cultures were harvested at $0,12,24$ and 36 $\mathrm{h}$ of the incubation period and proceed for SEM works as described previously by Borges [22]. The prepared samples were then viewed under SEM (Leica Cambridge, S-360, UK).

\section{Statistical analysis}

The data obtained in this study were analyzed by Student $t$-test for comparing the effect of ethyl acetate extract on test microorganism cells against control using SPSS Version 12.0. All tests were independently performed in triplicates. The results obtained were analyzed using a one-way ANOVA test and reported as the mean \pm SD. $P$ values $<0.05$ were considered statistically significant.

\section{RESULTS}

\section{MIC and MBC determinations}

The susceptibility test result for ethyl acetate crude extract is presented in table 1 . The result revealed that MBC value $(250.0$ $\mu \mathrm{g} / \mathrm{ml})$ was significantly higher than the MIC $(125.0 \mu \mathrm{g} / \mathrm{ml})$, indicating that the concentration of the fungal extract would have to be significantly increased to kill bacterial cells, instead of inhibiting their growth. The result also showed that the MBC/MIC ratio was 2 (which was less than 4). Hence, the fungal ethyl acetate crude extract possesses bactericidal effect towards MRSA.

Table 1: MIC and MBC values of the fungal ethyl acetate crude extract towards MRSA

\begin{tabular}{lll}
\hline Microorganisms & MIC $(\mu \mathrm{g} / \mathbf{m l})$ & MBC $(\mu \mathrm{g} / \mathbf{m l})$ \\
\hline $\begin{array}{l}\text { Methicilin-resistant S. aureus } \\
\text { (MRSA ATCC 33591) }\end{array}$ & 125.0 & 250.0 \\
\hline
\end{tabular}

\section{Time-kill study}

Time-kill study of the ethyl acetate crude extract of $L$. pseudotheobromae IBRL OS-64 against MRSA ATCC 33591 at different extract concentrations viz. 1/2MIC $(62.5 \mu \mathrm{g} / \mathrm{ml})$, MIC $(125.0 \mu \mathrm{g} / \mathrm{ml}), 2 \mathrm{MIC}(250.0 \mu \mathrm{g} / \mathrm{ml})$ as well as a control are shown in fig. 1 . At the extract concentration of $1 / 2 \mathrm{MIC}$, the MRSA cell was constantly growing at the lag phase mirroring the growth control. 
However, the viable cell counts slightly decreased after 4 until $8 \mathrm{~h}$ of incubation. Then, the bacterial growth was observed to be increased after $12 \mathrm{~h}$ of incubation and afterwards which reached the viable cell counts almost mirroring the control. The emergence of resistance cells revealed that the extract had not exerted a bactericidal effect on MRSA ATCC 33591 at low concentration such as at 1/2MIC. Besides that, there was a slight decline in a number of cell growth in the culture treated with the MIC concentration of extract from 0 to $8^{\text {th }} \mathrm{h}$. The decrement of viable cell counts was observed throughout the incubation period until all of the bacterial cells were killed after exposure to the extract for $48 \mathrm{~h}$.

Similarly, the viable cell counts of MRSA ATCC 33591 after treated with concentration extract of 2MIC showed the same pattern as at MIC. As for 2MIC, the bacterial growth started decreasing after $4 \mathrm{~h}$ of exposure to the extract and declining throughout the incubation period until it reached $36 \mathrm{~h}$ whereby all bacterial cells were killed. The time for killing activity of the extract on MRSA ATCC 33591 was shorter at higher concentration of extract (2MIC) as compared to lower concentration (MIC and 1/2MIC). The results revealed that the ethyl acetate crude extract of $L$. pseudotheobromae IBRL OS-64 possessed strong bactericidal effect against MRSA ATCC 33591 at higher concentration. The results also reflected that the bactericidal effect of the extract was concentration and exposure time dependent.

The time-kill study of control showed that the bacterial growth occurred exponentially until reaching its maximal bacterial concentration at the stationary phase. As for the lowest extract concentration $(1 / 2 \mathrm{MIC})$, the reduction of bacterial cell was observed in the first $4 \mathrm{~h}$ of exposure and the re-growth was then occurred.

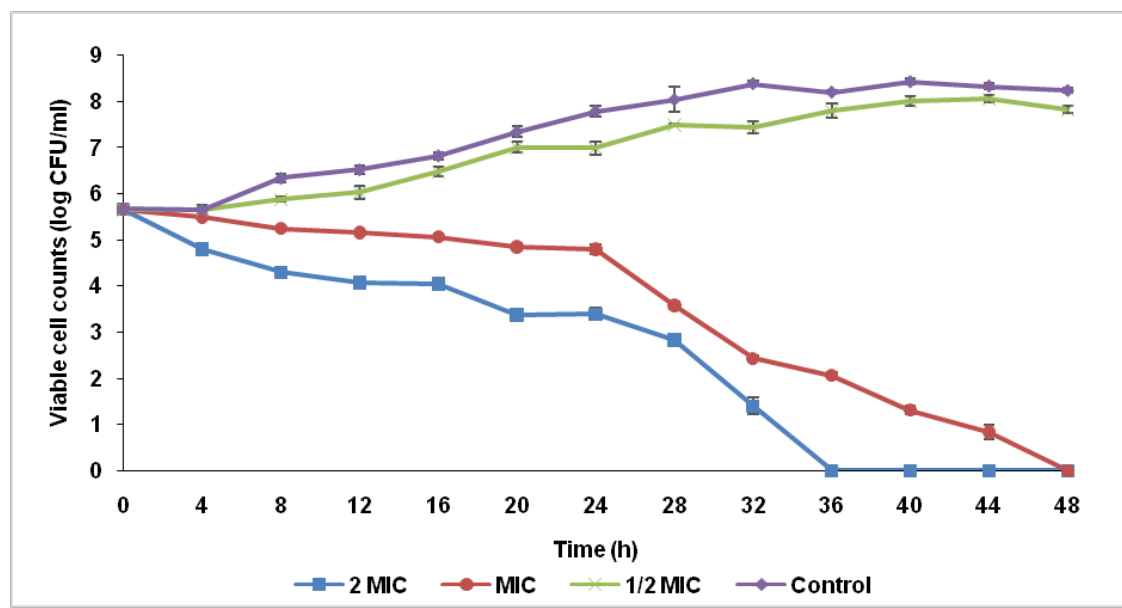

Fig. 1: Time-kill study of the ethyl acetate crude extract of $L$. pseudotheobromae IBRL OS-64 against MRSA ATCC 33591 at different extract concentrations [Triplicate readings were recorded, mean \pm SD]

Table 2 shows the time to achieve 25,50,90, 99, and 99.9\% growth reduction in initials inoculum of MRSA ATCC 33591. The result reflects that the longer incubation time was required to obtain a higher percentage of bacterial cell reduction. On the other hand, results also revealed that higher concentration of extract was required to exert in inhibiting or killing effects of MRSA cells.
Reduction in cell viability was only observed in the extract twice the concentration of the MIC. As shown in table 2, higher concentrations of the extract are capable to kill bacterial cells up to $99.9 \%$. In fact, at the highest concentration of extract (2MIC) shorter time was needed to reduce and killed the MRSA cells $(32-36 \mathrm{~h})$ as compared to the MIC value with incubation period in the range of $44-48 \mathrm{~h}$.

Table 2: The time to achieve 25, 50, 90, 99, and 99.9\% growth reduction in initial inoculum of MRSA ATCC 33591

\begin{tabular}{lllll}
\hline Percentage of reduction (\%) & Time (h) & & & MIC \\
\cline { 2 - 5 } & Control & 1/2 MIC & $4-8$ & 2 MIC \\
\hline 50 & NR & NR & $0-4$ \\
90 & NR & NR & $4-8$ & $4-8$ \\
99 & NR & NR & $16-20$ & $4-8$ \\
99.9 & NR & NR & $20-24$ & $16-20$ \\
\hline
\end{tabular}

Key: NR $=$ not reached

\section{Structural degeneration and morphological changes of the extract treated cells}

The effects of structural degeneration of MRSA ATCC 33591 cells after exposure to the ethyl acetate crude extract of $L$. pseudotheobromae IBRL 0S-64 were studied via SEM observations. Based on the comparison among the SEM micrographs, the ethyl acetate crude extract was found to affect significantly on the morphological changes and the degeneration of MRSA cell structures (fig. 2) of the treated and untreated (control) cells. Fig. 2a demonstrates the untreated or control cells with the presence of regular Gram-positive bacterial cells, undamaged and smooth surface with the intact spherical shape. The cells were also observed growing actively which indicated by the cells underwent binary fission (red arrows). After $12 \mathrm{~h}$ exposed to the extract (fig. $2 \mathrm{~b}$ ), the formation of small dimples and dents (red arrows) or cavities were observed which indicated the primary effect of the extract. Fig. 2c shows the bacterial cells after exposed to fungal extract for $24 \mathrm{~h}$. Results revealed that some of the bacterial cells become irregular in shape and bigger in size (black arrow). Despite of irregular shape, some of the bacterial cells were shrunken and crumpled. Fig. 2d illustrates the effect of fungal crude extract towards bacterial cells after $36 \mathrm{~h}$ of exposure time.

Severe damaged of the cell morphologies were observed as the cells envelope (cell wall) were broken (indicated by black arrow) and resulted in leakage of cytoplasm. The lysed cell walls were extremely devoid of cytoplasmic contents which led to completely collapsed and left only the homologous cell masses (or cells debris) which was indicated by red arrow). Eventually, the cell death completely occurred. 

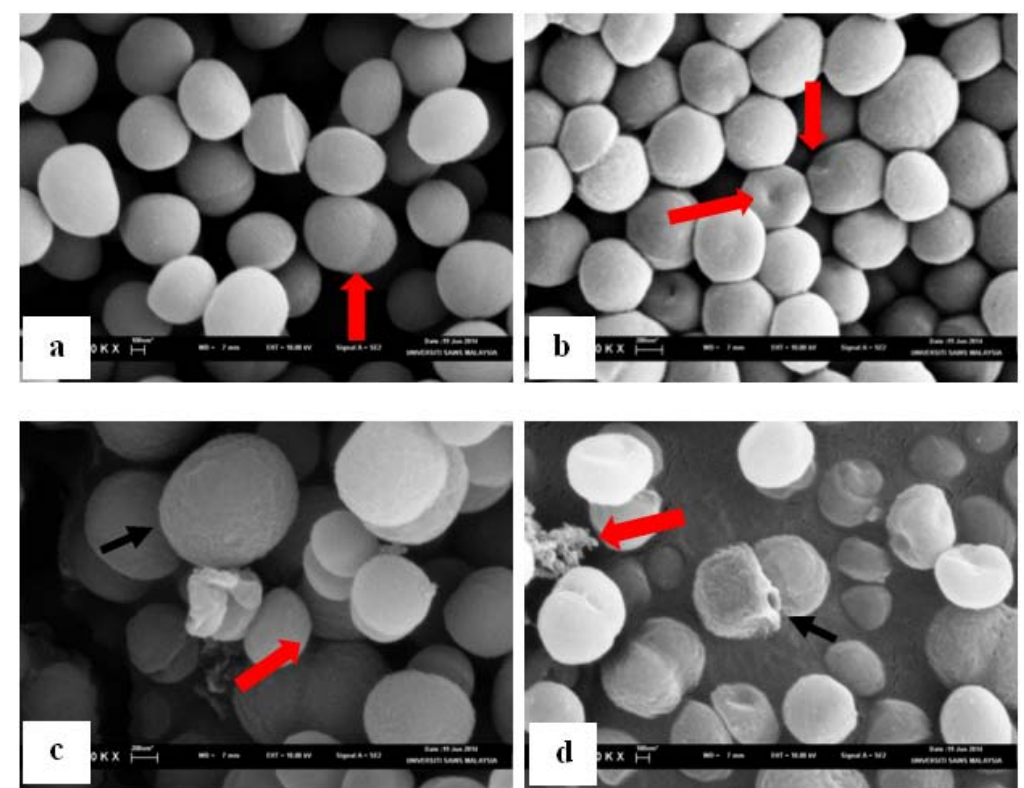

Fig. 2: SEM micrographs of the MRSA ATCC 33591 cells treated with $0.25 \mathrm{mg} / \mathrm{ml}$ of $L$. pseudotheobromae IBRL 0S-64 ethyl acetate crude extract at different exposure times, (a) $0 \mathrm{~h}$ [control] (b) $12 \mathrm{~h}$ (c) $24 \mathrm{~h}$ (d) $36 \mathrm{~h}$. Scale bars: $200 \mathrm{~nm}$

\section{DISCUSSION}

The development of resistance by existing pathogenic bacteria to commercial drugs is a relevant problem faced by health services and has become a serious concern around the world [23]. Several factors have favoured this scenario, such as the extensive and often inappropriate use of antibiotics, poor hygienic conditions, continuous movement of travellers, increased numbers of immunocompromised patients, and delay in diagnosis of infections [24]. As a result, an intensive search for new, effective antimicrobial agents is necessary, which is facilitated by exploring new niches and habitats $[25,26]$.

In the search for new anti-MRSA compounds, L. pseudotheobromae IBRL OS-64, an endophytic fungus residing in the leaf of $O$. sanctum, one of the medicinal plants that have many usages to treat various illnesses was isolated. Medicinal plants have been proven to accumulate a wealth of bioactive compounds and are thus chemically highly defended [27]. Any endophyte that is able to colonize these plants needs to cope with their chemical weapons that will restrict any successful microbial invasion [28]. Again, these pronounced stress conditions are expected to favour unusual endophytes that will give rise to likewise unusual metabolites [29].

The in vitro antibacterial activity of drugs is usually assessed by determining of the MIC and MBC levels after overnight aerobic incubation following standard protocols [20]. The MIC is defined as the minimal concentration of antibiotic that prevents a clear suspension of $10^{5}$ colony-forming units (CFUs) of bacteria/ml from becoming turbid after overnight incubation. Turbidity usually connotes to growth at least a 10 -fold increase in bacterial density. Because clear bacterial suspensions may have bacterial densities that are $10^{5} \mathrm{CFU} / \mathrm{ml}$ or less, the MIC may actually be bactericidal to some extent. The minimal bactericidal concentration (MBC) on the other hand is defined as the minimal concentration of an antibiotic that is bactericidal. It is determined by subculturing broth dilutions that inhibit the growth of test bacterial cells (i.e., those at or above the MIC level). The broth dilutions are streaked onto agar and incubated for 24 to $48 \mathrm{~h}$. The MBC is the lowest broth dilution of drug that prevents the growth of the test bacteria on the agar plate. Failure of the bacteria to grow on the plate implies that only nonviable organisms are present.

From the data obtained in this study, L. pseudotheobromae IBRL OS64 ethyl acetate crude extract on MRSA cells was found to be bactericidal. This was due to the low ratio of MBC/MIC values (equivalent to 2) where the MBC value was two-fold higher than
MIC. Levison [30] stated for bacterial drugs the MBC values are usually not more than four-fold higher than their MIC values.

Time-kill test has been used to investigate a wide range of antimicrobial agents and it is the most appropriate method for determining the bactericidal effect. It is a flexible alternative approach that provides more dynamic information regarding on relationship effect of concentration over the time of antimicrobial agents [31]. The time-kill test reveals a time-dependent or a concentration-dependent antimicrobial effect. This approach was frequently used as the basis in the investigation of pharmacodynamics drug interactions and it provides descriptive information on the pharmacodynamics of antimicrobial drugs [32]. The antimicrobial effect of various extract concentrations levels can be directly compared over a wide range of concentrations and times through this approach [33]. The result was consistent with the previous study in the bacterial kill-time curve of tedizolid [31]. At low extract concentration, the post-antibiotic effect might happen whereby the remaining bacteria will begin to resume their growth [34]. Biphasic killing curve with a decline in killing rate over the time was observed when bacterial cells were exposed to a lower concentration of the extract, indicating the presence of persister which less susceptible to antimicrobial drugs [35]. The regrowth phenomenon was attributed to two distinct subpopulations with different susceptibility in which the selective growing of resistant sub-population take over the preferential killing of the susceptible sub-population at a specified time of interaction [32].

The Time Kill Test is used in microbiology to assess a test object's in vitro antimicrobial activity in relation to time. Generally, in a TimeKill Test, a $3 \log _{10}$ reduction is considered the minimum level that would indicate a product has significant killing activity against a particular test microorganism, while, as in the minimal bactericidal (MBC) test, bactericidal activity is defined as a $99.9 \%$ or greater killing efficacy at a specified time. In conclusion, the results of the present study suggest that time-kill methodologies offer an in vitro approach to the initial selection of new agents or combinations of agents for therapy.

Usually the crude extracts of natural products, whether plants or microbial extracts would affect the cell wall biosynthesis and also the cell membrane permeability. As revealed by the results from SEM micrographs obtained from this study, the effects of the extract on MRSA cells were concentration and exposure time dependants. Meaning at higher concentrations (more than the MIC value) the extract causes the formation of cavities and small dents. The sizes and the depth of those cavities and dents increased as the 
concentration increased and the exposure time prolonged. The cell wall and cell membrane were destructed or disintegrated, possibly indicated the rupture of cell membrane as well. Hartmann [36] suggested the formation of holes, craters and dents on the surface of bacteria cells indicated a failure or a mechanism rupture of the cell wall and membrane. Besides that, the bacterial cells were observed to compactly resemble and clump together and this may due to stress response to the extract. According to Bible [37], cell-to-cell clumping is a special metabolic scavenging strategy by bacterial cells in order to prepare their cells for further stress conditions. Basri [2], found the MRSA cell treated with acetone extract which combined with vancomycin produced the bigger size of cells and the cell treated with solely acetone extract were in inhomogeneous and irregular shape. Watanabe [38] postulated that the use of arbekacin promoted the formation of thick cell walls of MRSA which could be due to the rapid continuation of cell wall biosynthesis whereby the cell division was inhibited. Some antibiotic including aminoglycosides able to inhibit the initial step in DNA replication and thus inhibited bacterial cell division, but they are not able to completely block the protein synthesis of the bacteria $[39,40]$. Besides that, the MRSA cells were observed to be in crumpled and shrunken stages. Ibrahim [41], stated that the reason of the irregular shape of bacterial cell treated with fungal extract (such as cell surface crumpled and shrinkage of the cells) could be due to extensive loss of cell organelles and also the leakage of cytoplasm, supported by the damage of cell envelope.

This condition also may be due to the initiation of cell's autolytic mechanisms and removal of crucial ions and molecules [42]. The collapsed cells with shrunken cell residues may represent the leakage or loss of cytoplasmic contents. Another interesting point is that MRSA is a Gram positive bacteria and is more susceptible to any antibacterial agents compared to Gram negative bacteria.

\section{CONCLUSION}

The result of this study revealed that the ethyl acetate crude extract of L. pseudotheobromae IBRL OS-64 exhibited bactericidal activity towards MRSA ATCC 33591 with time and concentration dependents. The fungal extract also showed antibacterial activity by disrupting the cell wall and cell membrane of MRSA which cause cell lysis and ultimate death.

\section{ACKNOWLEDGEMENT}

The authors are grateful to Universiti Sains Malaysia for awarding the RUI research grant scheme (ac: 1001/PBIOLOGI/811326) to support this study.

\section{AUTHORS CONTRIBUTIONS}

Taufiq MMJ did all the experiments including leaf sampling, isolation of endophytic fungi, antibacterial activity, time-kill study and structural degeneration (SEM). Darah I was the principle investigator and she supervised the whole works including sample preparation, isolation of endophytes, time-kill study, the antibacterial activity of extract as well as structural degeneration through SEM. All the works, except SEM was performed in her laboratory. She, along with Taufiq MMJ was prepared and corrected the manuscript.

\section{CONFLICT OF INTERESTS}

Authors have declared that no competing interests exist.

\section{REFERENCES}

1. Jindal AK, Pandya K, Khan ID. Antimicrobial resistance: a public health challenge. Med J Armed Forces India 2015;71:178-81.

2. Basri DF, Jaffar N, Zin NM, Santhana-Raj L. Electron microscope study of gall extract from Quercus infectoria in combination with vancomycin against MRSA using post-antibiotic effect determination. Int J Pharmacol 2013;9:150-6.

3. Vimala S, Ilham MA, Rashih AA, Rohana S. Nature's choice to wellness: antioxidant vegetables/ulam. Siri Alam and Rimba 7. Forest Research Institute Malaysia (FRIM); 2003. p. 131.
4. Pattanayak P, Behera P, Das D, Panda SK. Ocimum sanctum Linn. A reservoir plant for therapeutic applications: an overview. Pharmacogn Rev 2010;4:95-105.

5. Jose B, Reddy LJ. Evaluation of antibacterial activity of the leaf and flower of essential oils of Gliricidia sepium from South India. Int J Appl Pharm 2010;2:20-2.

6. Moorthy K, Aravind A, Punitha T, Vinodhini R, Suresh M, Thajuddin N. In vitro screening of antimicrobial activity of Wrightia tinctoria (Roxb.) R. BR. Asian J Pharm Clin Res 2012;5:54-8.

7. Menghani E, Sudhanshu, Rao N, Mittal S. Evaluation of the antimalarial and antioxidant effect of Parnassia nubicola methanolic extract. Int J Curr Pharm Res 2012;4:77-9.

8. Azevedo JL, Walter MJ, Pereira JD, Araujo WL. Endophytic microorganism: a review on insect control and recent advances on tropical plants. Electron J Biotechnol 2000;3:40-65.

9. Nagda V, Gajbhiye A, Kumar D. Isolation and characterization of endophytic fungi from Calotropis procera for their antioxidant activity. Asian J Pharm Clin Res 2017;10:254-8.

10. Faeth SH, Fagan WF. Fungal endophytes: common host plant symbionts but uncommon mutualists. Int Comp Biol 2002;42:360-8.

11. Sun JQ, Guo LD, Zang W, Ping WX, Chi DF. Diversity and ecological distribution of endophytic fungi associated with medical plants. Sci Chin Ser C 2008;51:751-9.

12. Castro-Medina F. First report on Lasiodiplodia pseudotheobromae causing trunk cankers in Acacia mangium in Venezuela. Plant Dis 2014;98:686.

13. Awan QN, Akgul DS. First report of Lasiodiplodia pseudotheobromae causing postharvest fruit rot of lemon in turkey. Plant Dis 2016;100:23-7.

14. Nogueira Junior AF, Santos RF, Pagenotto ACV, Sposito MB. First report of Lasiodiplodia pseudotheobromae causing fruit rot of persimmon in Brazil. New Dis Rep 2017;36:1.

15. Ismail AM, Cirvilleri G, Pollizzi G, Crous PW, Groenewald JZ, Lombard L. Lasiodiplodia species associated with dieback disease of mango (Mangifera indica) in Egypt. Australas Plant Pathol 2012;41:649-60.

16. Kwon JH, Choi O, Kang B, Lee Y, Park J, Kang PW, et al. Identification of Lasiodiplodia pseudotheobromae causing mango dieback in Korea. Can J Plant Pathol 2017;39:241-5.

17. Wei W, Jiang N, Mei YN, Chu YL, Ge HM, Song YC, et al. An antibacterial metabolite from Lasiodiplodia pseudotheobromae F2. Phytochemistry 2014;100:103-9.

18. Cimmino A, Cinelli T, Masi M, Reveglia P, Silva MA, Mugnai L, et al. Phytotoxic lipophilic metabolites produced by grapevine strains of Lasiodiplodia species in Brazil. J Agric Food Chem 2017;65:1102-7.

19. Tong WY, Nurul Zaadah J, Nurhaida, Tan WN, Melati K, Latiffah Z, et al. Antimicrobial activity of Phomopsis sp. ED2 residing in medicinal plant Orthosiphon stamineus Benth. Annu Res Rev Biol 2014;4:1490-501.

20. Jorgensen JH, Ferraro MJ. Antimicrobial susceptibility testing: General principles and contemporary practices. Clin Infect Dis 1998;26:973-80.

21. Andrews JM. Determination of inhibitory concentration. J Antimicrob Chemother 2001;48:5-16.

22. Borges M, De-Ven MA, Van-Cutsem J. Structural degeneration of Aspergillus fumigatus after exposure to saperconazole. J Med Vet Mycol 1989;27:381-9.

23. Aksoy DY, Unal S. New antimicrobial agents for the treatment of Gram-positive bacterial infections. Clin Microbiol Infect 2008;14:411-20.

24. Nussbaum F, Brands M, Hinzen B, Weigand S, Habich D. Antibacterial natural products in medicinal chemistry-exodus or revival? Angewandte Chemie 2006;45:5072-129.

25. Xing YM, Chen J, Cui JL, Chen XM, Guo SX. Antimicrobial activity and biodiversity of endophytic fungi in Dendrobium devonianum and Dendrobium thyrsiflorum from vietnam. Curr Microbiol 2011;62:1218-24.

26. Zhao K, Penttinen P, Guan T, Xiao J, Chen Q, Xu J, et al. The diversity and anti-microbial activity of endophytic actinomycetes isolated from medicinal plants in Panxi Plateau, China. Curr Microbiol 2011;62:182-90. 
27. Yang L, Yang $\mathrm{C}$, Li C, Zhao $\mathrm{O}$, Liu L, Fang $\mathrm{X}$, et al. Recent advances in biosynthesis of bioactive compounds in traditional Chinese medicinal plants. Sci Bull 2016;61:3-17.

28. Doughari JH. An overview of plant immunity. J Plant Pathol Microbiol 2015;6:322.

29. Kohlmeyer J, Kohlmeyer E. Marine mycology, the higher fungi. Mar Ecol 1979;1:103-4.

30. Levison ME. Pharmacodynamics of antibacterial drugs. Infect Dis Clin North Am 2000;14:281-91.

31. Nunart T, Chatsuwan T, Treyaprasert W. Time-kill study of the in vitro antimicrobial activity of tedizolid against methicillinresistant Staphylococcus aureus. Thai J Pharm Sci 2017;41:25-9.

32. Tam VH, Schilling AN, Nikolaou M. Modelling time-kill studies to discern the pharmacodynamics of meropenem. J Antimicrob Chemother 2005;55:699-706.

33. Mueller M, Pena A, Derendorf H. Issues in pharmacokinetics and pharmacodynamics of anti-infective agents: kill curves versus MIC. Antimicrob Agents Chemother 2004;48:369-77.

34. Ingerman MJ, Pitsakis PG, Rosenberg AF, Levison ME. The importance of pharmacodynamics in determining the dosing interval in therapy for experimental Pseudomonas endocarditis in the rat. J Infect Dis 1986;153:707-14.

35. Nielsen EI, Anders Viberg A, Elisabeth Lowdin E, Otto Cars O, Mats 0, Karlsson MO, et al. Semimechanistic pharmacokinetic/ pharmacodynamic model for assessment of activity of antibacterial agents from time-kill curve experiments. Antimicrob Agents Chemother 2007;51:128-36.
36. Hartmann M, Berditsch M, Hawecker J, Ardakani MF, Gerthsen D, Ulrich AS. Damage of the bacterial cell envelope by antimicrobial peptides gramicidin S and PGLa as revealed by transmission and scanning electron microscopy. Antimicrob Agents Chemother 2010;54:3132-42.

37. Bible AN, Khalsa Moyers GK, Mukherjee T, Green CS, Mishra P, Purcell A, et al. Metabolic adaptations of Azospirillum brasilense to oxygen stress by cell-to-cell clumping and flocculation. Appl Environ Microbiol 2015;81:8346-57.

38. Watanabe T, Ohashi K, Matsui K, Kubota T. Comparative studies of the bactericidal, morphological and post-antibiotic effects of arbekacin and vancomycin against methicillin-resistant Staphylococcus aureus. J Antimicrob Chemother 1997;39:471-6.

39. Dubin DT, Hancock R, Davis BD. The sequence of some effects of streptomycin in Escherichia coli. Biochim Biophys Acta 1963;74:476-89.

40. Matsunaga K, Yamaki H, Nishimura T, Tanaka N. Inhibition of DNA replication initiation by aminoglycoside antibiotics. Antimicrob Agents Chemother 1986;30:468-74.

41. Ibrahim D, Chai Lee CC, Yenn TW, Zakaria L. Sheh-Hong L. Effect of the extract of endophytic fungus, Nigrospora sphaerica CL-OP 30, against the growth of methicillin-resistant Staphylococcus aureus (MRSA) and Klebsiella pneumoniae cells. Trop J Pharm Res 2015;14:2091-7.

42. Denyer SP. Mechanisms of action of biocides. Int Biodeterior Biodegradation 1990;26:89-100. 